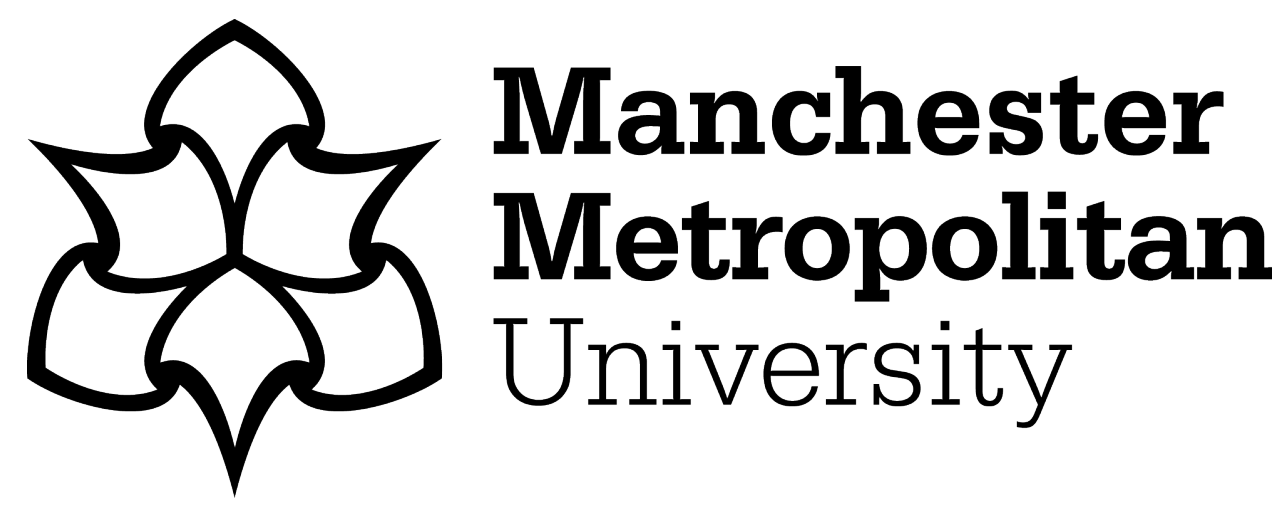

McDonnell, J (2018) Is it 'all about having an opinion'? Challenging the Dominance of Rationality and Cognition in Democratic Education via Research in a Gallery Setting. International Journal of Art and Design Education, 37 (2). pp. 233-243. ISSN 1476-8070

Downloaded from: https://e-space.mmu.ac.uk/620862/

Publisher: Wiley

DOI: https://doi.org/10.1111/jade.12107

Please cite the published version 


\section{Is it 'all about having an opinion'? Challenging the Dominance of Rationality and Cognition in Democratic Education via Research in a Gallery Setting}

\section{Jane McDonnell}

\section{Abstract}

This article reports on findings from a research study exploring the potential for democratic learning in a gallery education project which took place in the UK in 2006-7. In doing so, it also explores a pressing issue for education today: the question of young people's democratic education in a time of political crisis in Europe. The focus of the article lies in a critique of the primacy of rational thought, cognitive skills and verbal discussion within democratic education, and an exploration of the potential role of the arts and art education in challenging this. Specifically, the article argues that there has been an affective and corporeal deficit in democratic education, and that some forms of gallery education are well placed to address this. Although the data discussed derive from a particular time and place (the UK in the latter days of a government that rigorously pursued an agenda of social and economic inclusion through both education and cultural policy), they also have relevance beyond their immediate context, illuminating the nature and dynamics of the process of democratic learning, and its aesthetic and artistic dimensions.

\section{Introduction}

The quotation in the title is taken from a wall display created by school pupils and student teachers at a UK university, following the introduction of citizenship education as a statutory subject for secondary schools in England and Wales in 2002. Introduced by the then Labour government, the subject aimed to develop in students the, 'values, skills and understanding' (Crick 1998, 13) necessary for democratic citizenship. Similar developments occurred in Scotland at around this time: for example, via an emphasis on the formation of 'responsible citizens' in the new Curriculum for Excellence (Education Scotland 2015). Since its introduction, citizenship education has so far been retained in the curriculum by the Coalition and now Conservative governments, with a renewed emphasis on knowing about legislature, and the introduction of financial responsibility, within the subject's aims following the recent curriculum review (Department for Education 2013).

Such programmes of mass political education have aimed to produce students with the kinds of capacities expected of democratic citizens, and are problematic for a number of reasons. Osler \& Starkey (2003), for example, have highlighted the difficulty of defining citizenship, whilst others have noted the apolitical nature of citizenship education (Frazer 2007) or even argued that it masks deeper issues of inequality and injustice (Gillborn 2006; Faulks 2006). Biesta \& Lawy (2006) have offered perhaps the most radical critique, questioning the philosophical and educational foundations of the subject. They argued that in the effort to produce good or 'active' citizens, citizenship education relied on a deficit model of young people (as 'not-yet' citizens), an instrumentalist view of education (as a tool for producing social and political ends) and an individualistic view of democracy (as the aggregative effect of creating individual democratic citizens).

I take these critiques to be important and valid. To assume a set of qualities pertaining to citizenship, which young people need to achieve, certainly runs the risk of viewing citizenship in exclusive terms. It is also clear that creating a large number of democratic citizens (if this were indeed possible) would not necessarily result in a healthy democratic citizenry. However, in this article I wish to focus on another, particular problem with citizenship education, and other forms of democratic education: the emphasis on rationality, cognition and deliberative discussion. 
The quotation above already highlights this problem, stipulating that students ought to learn 'that having discussions and forming opinions about issues and current events are central to citizenship' (Qualifications and Curriculum Authority 2007). Whilst this rational and discursive interpretation of democratic citizenship is a valid one, it also raises many questions. What if someone does not have an opinion? What if they are unable or unwilling to express it in a 'rational', discursive way? What does that say about their citizenship? And what does that say about our democracy? This article addresses these questions via a discussion of research carried out in relation to a gallery education project.

\section{An affective and corporeal deficit in democratic education}

The questions above are not only a concern for citizenship education. Other forms of democratic education in the UK have also placed an emphasis on rational discussion and deliberation. The student voice movement, for example, reviving the older tradition of democratic schooling within more mainstream settings, primarily encouraged participation in democratic fora such as student councils and governing bodies and (nationally) the Youth Parliament, all of which rely on discussion and debate. Rudduck \& Fielding (2006) have questioned the extent to which such work really embodied the values of democratic schooling. However, this tradition itself has been characterised by democratic participation conceptualised discussion. Perhaps the most emblematic example of this tradition, A. S. Neill's Summerhill (see e.g. Croall 2013) does, after all, rely on direct participation in school governance as one of the main forms of democratic experience for students, famously via the weekly moot, in which rules and their implementation are discussed.

In public education too, there has been an emphasis on discursive and mainstream participation. In the context of the recent general election and referendum on Scottish independence in the UK, a number of political education campaigns have grown up, encouraging young people to vote and to be well informed at the ballot box. With 16 and 17 year-olds given the right to vote at a national level for the first time, the Scottish government set aside time within the school curriculum for the development of political literacy. Within such campaign, this is often understood in cognitive terms, as is aptly captured in the literature of one such campaign group, Democracy Matters, which claims that 'for an effective democracy, political literacy is just as important as the ability to read and write' (Democracy Matters 2014).

This emphasis on discussion perhaps also reflects a growing interest in deliberative democracy (see, e.g. Warren 2002) in political theory over the past two decades. In educational terms, this has led to more opportunities to exercise important skills such as the expression of opinion, openness to debate, willingness to be challenged and the ability to reformulate one's views in the light of others'. Englund (2000) has argued that deliberative democracy is also inherently educative, offering opportunities for transformation, growth and development. Deliberative discussion also has its limitations, however, as Young (2000), amongst others, has pointed out. An over-emphasis on rational debate and discussion within democratic education risks ignoring other important experiences that are less overtly democratic and political but, nevertheless, are crucial to young people's learning. The concerns discussed above point to an affective and corporeal deficit in democratic education, in which the significance of emotion, affect and the body are underplayed in how democracy is conceived.

The arts and democratic education 
The arts have often been seen as a way of addressing similar deficits in education more generally. Often this has been framed in instrumentalist terms, with the arts seen as a 'tool' for achieving desired educational ends. Karkou \& Glasman (2004), for example, have argued that arts therapy in schools can help to re-engage young people who have become disaffected from the curriculum. Elsewhere, Simons \& Hicks (2006) have argued for the use of the creative arts within a more inclusive approach to higher education. Such arguments, of course, have an older history in the expressivist tradition of arts education in schools in the UK in the 1960s and 1970s. Heavily influenced by the work of Herbert Read, this tradition has been critiqued by Abbs (2003) for approaching a therapeutic rather than educational view of the value of art.

Politics and democracy also feature in such arguments. Read's project of 'education-through-art' of course had a moral, social and political agenda at its heart (Barchana-Lorand 2015). The community arts movement, too, has seen the arts as a vehicle for the achievement of social and political goals such as transformation and empowerment. For the New Labour government that also introduced citizenship education, investment in the arts was seen as part of a broader agenda of 'social inclusion' which married the older, collectivist concerns of the Labour Party with the more neoliberal and neoconservative politics of enterprise and cohesion (Buckingham \& Jones 2001). Houston (2005), in a broader argument about the risks of championing the civilising and transformative power of art, illustrates how some community arts projects at the time were credited with a whole series of social and political gains, including a reduction in crime.

More radical conceptions of the relationship between democracy, education and the arts also exist, of course. Hickey-Moody $(2013,1)$, for example, has emphasised the active role of young people in using the arts for their own political engagement, arguing that 'the arts are not technologies for social control; they are methods through which young people become themselves and can express opinion and critique through style'. Whilst making an important contribution, this argument continues to frame the arts as a tool: the crucial question being who uses them, and to what ends. Writing on ensemble theatre, Neelands $(2009,173)$ has argued for a view of this art form as a 'model of democratic living', offering a less instrumentalist framework for valuing the political and democratic aspects of the arts, focused more on experience than outcome.

Within gallery education, research has often focused on what makes the gallery setting distinctive. Pringle (2009), for example, has argued that galleries offer important opportunities for constructivist learning via a complex process of meaning-making involving the varied (and often competing) interpretations of artists, visitors, gallery educators and art works on display. She also highlights how gallery education offers a unique opportunity to work directly with artists. Illeris $(2005,231)$ has argued that the contemporary art gallery is an ideal space for providing meaningful educational experiences for a generation of young people characterised by 'new forms of consciousness', and has also written on the aesthetic qualities of experimental educational practices in galleries. Fulkova et al.'s (2004) research on students' responses to contemporary art makes a case both for new forms of visual practice in contemporary galleries and for the shift towards more constructivist approaches in gallery education.

Such arguments can also be problematic. Whilst Illeris $(2005,239)$ insists it is important to view young people as individuals, rather than a 'unified and "perfect" audience', her reliance on psychological conceptions of new forms of consciousness amongst people born since the 1970s veers towards determinism. Equally, the constructivist view of learning that Pringle advances is only one educational approach. However, this body of work opens up ways of seeing the value of gallery education in ways that take both the artistic and educational qualities of this seriously, often drawing on theoretical work that favours more experiential conceptions of art: for example 
Borriaud's 'relational aesthetics' (IIleris, 2005, 235). The research reported in this article also aimed to develop a less instrumentalist way of theorising the value of non-formal arts education in the gallery setting.

\section{The aesthetics of democratic learning}

The research worked with a theorisation of democratic learning as a process of experiencing and reflecting on democratic subjectivity, itself understood as an aesthetic process that can also be facilitated through the arts. Particularly significant here is Biesta's (2010) concept of learning from democracy, understood as the experience of democratic subjectivity, which, following Arendt, he argues is something which arises through political existence under the conditions of freedom, plurality and unpredictability. Instead of thinking about democratic learning as a psychological process in which individual democratic beings are created or engendered, Biesta (2010) argues that we ought to think about it in political terms, as a process of learning from the experience of democratic subjectivity, which emerges through free interaction with others who are unlike us.

Drawing on Rancière $(2004,2006)$, this was also understood within the research to have an aesthetic dimension. For Rancière, democracy occurs in the moments when people's actions cause a rupture in the given distribution of roles, places and positions within a political community. Such moments involve a process of subjectification, in which people become politically subject or take up subject positions that were previously inconceivable. What is particularly interesting is that, for Rancière, every democratic rupture is also an aesthetic rupture in the 'distribution of the sensible' which apportions 'what is seen and what can be said about it, around who has the ability to see and the talent to speak, around the properties of spaces and the possibilities of time' (Rancière 2004, 13). The arts can also contribute to democracy by creating 'channels of subjectivisation' (Rancière, 2004, 38) which, depending on whether they are more unifying or disruptive, can act in parallel to democratic and political action.

Bishop $(2012,18)$ has argued that Rancière's work has 'rehabilitated the idea of aesthetics' for the art world, and 'connected it to politics as an integrally related domain'. She mobilises his work to argue for a deeper consideration of the artistic and aesthetic qualities of participatory and collaborative art. Whilst not opposed to collaborative and participatory art itself, Bishop makes a convincing argument for the need to evaluate art work in aesthetic as well as functional terms. In a critique of the evaluation of art in terms of its social application, Bishop $(2012,23)$ argues that 'art enters a realm of useful, ameliorative and ultimately modest gestures, rather than the creation of singular acts that leave behind them a troubling wake'. This also has implications for democratic education, echoing Rancière's $(2006,91)$ concept of democracy as a dynamic whose, 'constancy is only ever entrusted to singular acts' and the application of his work in art education: for example, in Atkinson's $(2012,5,14)$ argument for 'pedagogies of the event' that support 'encounter[s] with the real'and the reconfiguring of subjectivity. Since the gallery project involved a significant element of participatory and performance art, Bishop's (2012) work provides an important analytical framework for interpreting the young people's experiences.

\section{The research}

The research was carried out as part of a larger project co-ordinated by Engage, the national association for gallery education, and involved three galleries in one regional cluster. Drawing on 
other examples of collaborative work in galleries, and constructivist theories of gallery education (Pringle 2009), the project aimed to foster democratic practice in the gallery setting: both by involving young people directly in producing and displaying their own work, and by encouraging them to work democratically with each other to do so. Groups of young people drawn from two local secondary schools and one pupil referral unit worked with local artists to produce and display work in each of the galleries.

Whilst research was carried out in each of the three settings, this article focuses on work in one gallery in particular: partly because of the rich data that was gathered in this context and partly because of the experimental approach adopted by the artist. Beginning with a consensus model of democracy, she quickly adapted this to incorporate other, more creative strategies. Equally, whilst the project began with the young people's responses (mainly drawings and sculpture) to an existing exhibition (an installation involving human figures with heads of the Egyptian god Anubis in everyday situations and images seemingly drawn from advertising and entertainment), this progressed to include more performative activities, sometimes in response to the students' suggestions. Visiting the local museum to find out more about Anubis became an opportunity for performance art, for example.

Data collection consisted of a group interview with the artists at the beginning of the project, participant observation of the project days, individual and group interviews with participants and the collection of artists' journals. In addition, three individual interviews were carried out with five participants from the project during the 18 months following completion, at roughly six-monthly intervals. Whilst this design provided a breadth of study in relation to the cluster as a whole, it also afforded a depth of perspective in relation to the gallery setting discussed in detail here and a longitudinal dimension allowing exploration of the impact of the project over time. The research adopted an interpretivist version of grounded theory, based on the work of Charmaz (2006). Data from initial phases of collection in the form of field notes and transcriptions were coded and analysed via commonly recurring themes (with a focus on action and processes), to construct tentative categories. These then formed the basis for exploration in later rounds of data collection. Emerging interpretations were shared with the participants as part of a collaborative approach to constructing findings within the interpretative process (Silverman 2005). Five final categories (decision-making, participation, creativity, identity and change) were constructed through increasingly analytical phases of coding.

\section{Findings}

The findings presented below are drawn from three of the five key categories to emerge from data analysis: decision-making, participation and change.

\section{Making collective decisions without talking}

From the outset, the artist aimed to provide opportunities for decision-making based on action as well as discussion. A journal extract written in preparation for the first project day outlines a list of principles and objectives to be read out to students on the first day, including:

"We will be talking and moreover we will be decision making through DOING." (artist's journal, project day 1)

This often occurred through the arts activities. In the extract below, the young people had been asked to demarcate the 'art space' for the day: 
" Laura [the artist] explained that we would be doing lots of different tasks today and started by asking Jim, one of the students, to use masking tape to mark out on the floor where the 'art' would be. Jim started to do this and as he went around marking out a space, it was necessary for him to negotiate with the other students where to mark out the space, as they needed to decide together if some of them needed to move or not. It was interesting to see a decision making process being carried out in this very active way that did not involve discussion as such, but a physical negotiation of space." (observation notes, project day 2)

This required the young people to make decisions by physically moving, rather than discussing. The extract below offers another illustration. In this case, the students were asked to develop their own decision making strategy for taking a route through the city:

"The group were given three minutes to decide their decision making strategy and their medium for recording the route. At the end of three minutes, Emma, one of the students who seemed to act as a natural spokesperson for the group, explained that they had decided to follow a person with interesting shoes, then allow someone else in the group to identify another interesting pair of shoes and follow that person until each person in the group had had a chance to pick a pair of shoes and follow the person wearing them. They had decided to record their route by talking into a dictaphone. Carly volunteered to record the route on tape." (observation notes project day 2)

Whilst the strategy itself was agreed upon following discussion, individual decisions within the activity were based on aesthetic judgement and implemented through physical movement.

\section{Participating and performing in the public sphere}

The project took on a more public dimension as it progressed. Often this involved decisions about whether and how to participate within the small-scale 'public' of the project group:

"Ask the students to remove whatever is not art. They remove bags and chairs out of the art space. Request they take turns to make an individual contribution. A performative situation arises. Audience and performer. They all contribute and do not seem fazed by this. They are really thinking." (artist's journal, project day 2)

At other times, the students' art work resulted in a kind of ephemeral performance, also involving a public dimension, although one limited to the public visiting the gallery at the time:

"Back to gallery to look at the work where we had left it. A chance to see with fresh eyes. Members of the public in gallery space. Hard to distinguish which was the work - i.e. did the public consider the students' work part of the exhibition. The students' installations became part of the installation for a brief time. The Anubis figures looked like they had been doing drawings." (artist's journal, project day 1 )

Other performances took place within the wider, perhaps more fully 'public' sphere of the city centre. Following the route planning activity outlined above, the young people were invited to take part in another art activity:

"Laura explained that we would be doing an activity to help us think about moving in space and about standing out in a public space. Laura looked around the group, explaining that she was looking for something that stood out. Sally, one of the students, was carrying a bright blue folder and was asked to go and stand in the middle of the open space, holding up the 
bright blue folder. The rest of the group looked on and were asked to notice whether people were looking at Sally. A couple of students commented that people were looking more at us. Two other students were then asked to go and stand in the open space at a distance from each other, each with something that stood out. Claire held a bright orange scarf and Tommy held a large piece of white paper. The rest of the group looked on and took some photos. Laura then asked us all to go into the space together. Craig and Jim chose to stay around the edge of the space and took photographs with Steve [a teaching assistant present on the day]. Those of us in the centre were asked to think of a way of standing that would highlight our shoes ... Finally, Laura asked the group to experiment with space by each standing on a different spot on the floor. We noticed people's reactions, took photos and commented on how the use of space drew attention to the students standing at varied distances in a public space." (observation notes, project day 2)

Here the performance was again corporeal. It involved physical movement, the positioning of objects and bodies. The aesthetic dimensions of the activity are evident in the choice of brightly coloured objects. The public, participatory and performative elements of this activity are highlighted in the reactions of onlookers and the interchange of observation. Similar elements are highlighted in the artist's journal relating to the earlier, route planning activity:

"People are noticing us as a group. A lady comes up to me to ask us what we are doing! She is intrigued. And smiling! ... A few dodgy moments when they seem to be loud and vocally following 'the lady in the boring shoes'." (artist's journal, project day 2)

The data here highlights the risky and unpredictable elements of such public performance. Such risks, and the courage needed to participate were also something that also emerged in the students' reflections on the performance:

"Claire commented that she had enjoyed doing performance work in a public space. Laura remarked on how brave they had been to do that work. Craig commented that he and Jim had not participated in this but I remarked that by taking the photographs in a public space they had been part of that activity and Steve said that this required being brave as well." (observation notes, project day 2)

\section{Changing perceptions and adapting behaviour}

The dynamics of participation, creativity and decision making changed over time. Both the young people and the artist adapted to the circumstances and adopted more and less spontaneous approaches. Reflecting on the first project day in her journal, she noted the difficulties associated with a consensus view of decision making, which also highlights some fundamental dilemmas in relation to democracy:

"Difficult for group to respond - still uncommunicative so I have to ask for individual responses. I feel it is important to hear everyone's views ... difficult to continue discussing exhibition beyond this as group still quiet. Feel bad that I have had to 'pick on' people to talk." (artist's journal, project day 1 )

The young people also noted the shock and unfamiliarity of being allowed and expected to make their own decisions collectively. Jacob's comments below aptly illustrate this:

"Well I've kind of grown used to being told what to do and how to ... well not how to do it but just to do it, and then Enquire came and it was a bit of a shock because we were given choices of what to do and when to do it." (Jacob, interview 2) 
This experience led the artist to introduce more activities, less discursive activities such as those mentioned above, to encourage different approaches to collective decision making whilst simultaneously introducing new art forms. In doing so, she also adopted a more spontaneous attitude in her own practice as an educator/ facilitator:

"Students quickly engage in activity in art space among the shoe installation. Then another one minute of shoe drawing - I am veering off my plan and working spontaneously!" (artist's journal, project day 2)

Clearly, the artist was willing and able to adapt to the students' responses in terms of decision making. In her approach to creativity, there was also an element in which she aimed to encourage experimentation, spontaneity and open-endedness, as well as introducing the students to different art forms, which, interestingly, was sometimes in tension with the decision making, democratic objectives of the project:

"Not entirely happy students have already made a decision on final product. Want them to experience a multi-disciplinary investigation, a series of ideas and have no fixed outcome until we reflect on production - then start an edit/ post production process towards end of project." (artist's journal, project day 2)

These tensions were something that the artist had to negotiate as she worked out how best to facilitate the young people's art work and decision making. However, the young people adapted to this and became more comfortable with experimentation over the course of the project:

"I don't know, it's interesting, it's very sort of like original, unique. It's not like, it's different to the sort of stuff we do nowadays or in school at the moment I suppose. It's very much like taking its own path and we're not probably encouraged to do that so much in school." (Emma, interview 2)

"I think everyone did really enjoy it as well because it was nice not to have to plan everything out ... yeah it was quite interesting how we could just do that and how - because you've still got an end point and we still did something - and you don't always have to think through everything, it is alright to just sort of ... spur of the moment kind of thing." (Claire, interview 3)

At times, this awareness and willingness to experiment seemed to translate to the students' experiences beyond the project. Claire explained how she had become comfortable with more experimental and open-ended approaches in her creative writing:

"I'm not as fussed any more, like with English, we're doing like writing, writing in different styles of people and the first one I did linked really well to this author and so I was just like, 'fine, I'm going to do that' and just sort of set my mind on that, whereas as we've gone through and looked at different things and sort of was happy to leave something behind and start on something new and just sort of try different things. It's more interesting than just sticking with one thing, which does get a bit boring when you haven't experienced the others, you're sort of like making a judgement when you haven't got all the information if you know what I mean." (Claire, interview 3 )

In one instance this extended to political and democratic experiences. Commenting on a boycott of their school canteen, Emma remarked on her reading of the students' political action: 
"In my opinion, it would've been so much more effective if we'd all just like stood or like sat or even like gone into the canteen ... it would have been more effective if everyone had brought packed lunch and everyone had gone into the canteen and sat there in silence it would have had the most effect." (Emma, interview 3)

Whilst not necessarily a result of her participation in the project, it is possible to see a link here between Emma's increasing interest in 'original' and 'unique' art forms, the kinds of activities undertaken on the project and her increased appetite for aesthetic and artistic modes of political engagement.

\section{Discussion}

The research offers a number of important insights. Firstly, the project afforded opportunities for collective decision making through arts activities involving the body and senses. At times, decisions were literally made aesthetically and corporeally. Not all of these decisions could be described as democratic of course; in some cases the decision making involved those with the most confidence or loudest voices taking charge. In others, more egalitarian and inclusive strategies were taken, for example in the demarcation of 'art space'. They do, however, illustrate the potential for democratic decision making in corporeal and aesthetic terms. It is important to qualify this however. Within the project, the artist's approach was crucial in allowing for a variety of decision making experiences to occur. It was in part the commitment to spontaneity and experimentation that allowed the artist to facilitate opportunities for collective decision making in corporeal terms and in ways that might lead to the kind of democratic subjectivity envisaged by Biesta (2010) in his reading of Arendt. This also points to an interesting dynamic however, in which the artist's commitment to experimentation and spontaneity in the creative process was sometimes in tension with a need to make decisions and get things done.

Secondly, the research illustrated the significance of collaborative and performance art within the students' learning. One of the principal ways in which the young people experienced opportunities for democratic subjectivity was through performance in the public sphere, often through participatory art involving both themselves and the public or other 'publics': for example, the performance in the public square and the incorporation of their work in the gallery. Again, whilst not necessarily democratic, these experiences involved the students in unpredictable situations that required interaction (though non-verbal) with different people. In this sense, they also carried the potential for democracy. The gallery project afforded opportunities for performance and participatory art that were also deeply aesthetic. In this sense, they embodied the Rancièrian rehabilitation of aesthetics that Bishop (2012) alludes to in her work. An important feature of the project was the engagement with a variety of art forms (including installations, drawings and sculpture, as well as more participatory forms) and the fluidity of movement between these both within and beyond the gallery setting. Along with the opportunity to engage with contemporary art and interact directly with artists (Pringle 2009; Illeris 2005, 2006), this may be an important distinguishing feature of gallery education.

Finally, the research indicates the performative nature of democratic learning itself. The students' reflections indicate that they learned from the project, both in terms of their approach to art, and in terms of how comfortable they felt with uncertainty, unpredictability and spontaneity. The democratic and political features of this are evident in the ways in their increased openness to the kind of unpredictability necessary for democratic subjectivity to occur, but also in the consideration of aesthetic strategies for democratic and political action. What is particularly interesting about this project is that the corporeal and aesthetic dimensions of the young people's experiences hint at 
another kind of democratic learning. Building on the view of democratic and political subjectification as inherently aesthetic as outlined in Rancière $(2004,2006)$ work, and the educational implications of this as alluded to in the 'troubling wake' (Bishop 2012, 23) of artistic acts and Atkinson's $(2012,5)$ artistic 'pedagogies of the event', the research indicates that, at times, the students were learning not for, about, through or even from democratic subjectivity (although some of these aspects were also important) but in the performance of subjectivity itself.

\section{Conclusion}

This article has challenged the dominance of rationality and cognition within democratic education by illustrating the moments in which potentially democratic moments are experienced as aesthetic events involving the body and senses. In doing so, it highlights the particular role that gallery education may play in providing opportunities for learning in and from such experiences in ways that retain a genuine consideration for the aesthetics of the arts activities involved. To do so in ways that ensure such opportunities genuinely leave room for democracy, however, the research indicates that a delicate balance needs to be struck between the commitment to spontaneity in art and the commitment to unpredictability in life.

\section{References}

Abbs, P. (2003) Against the Flow: Education, the Arts and Postmodern Culture. Abingdon: Routledge.

Atkinson, D. (2012) Contemporary art and art in education: the new, emancipation and truth, International Journal of Art \& Design Education, Vol. 31, No. 1, pp. 5-18.

Barchana-Lorand, D. (2015) Art conquers all?, Herbert Read's education through art, International Journal of Art \& Design Education, Vol. 34, No. 2, pp. 169-79.

Biesta, G. J. J. (2010) How to exist politically and learn from it: Hannah Arendt and the problem of democratic education, Teachers College Record, Vol. 112, No. 2, pp. 557-72.

Biesta, G. J. J. \& Lawy, R. (2006) From teaching citizenship to learning democracy: overcoming individualism in research, policy and practice, Cambridge Journal of Education, Vol. 36, No. 1, pp. 6379.

Bishop, C. (2012) Artificial Hells: Participatory Art and the Politics of Spectatorship. London: Verso.

Buckingham, D. \& Jones, K. (2001) New Labour's cultural turn: some tensions in contemporary educational and cultural policy, Journal of Education Policy, Vol. 16, No. 1, pp. 1-14.

Charmaz, K. (2006) Constructing Grounded Theory: A Practical Guide through Qualitative Analysis. London: Sage.

Crick, B. (1998) Education for Citizenship and the Teaching of Democracy in Schools: Final Report of the Advisory Group on Citizenship and the Teaching of Democracy in Schools. London: Qualifications and Curriculum Authority.

Croall, J. (2013) Neill of Summerhill. The Permanent Rebel. Abingdon: Routledge.

Democracy Matters (2014) Democracy Matters: Alliance for Learning Practical Politics (online). Available at: www.democracymatters.org.uk/ (accessed 1 December 2014)

Department for Education (2013) Statutory Guidance: National Curriculum in England: Citizenship Programmes of Study for Key Stages 3 and 4 (online). Available at: 
www.gov.uk/government/publications/national-curriculum-in-england-citizenship-programmes-ofstudy (accessed 1 December 2014)

Education Scotland (2015) What is the Curriculum for Excellence?: Understanding the Curriculum as a Whole (online). Available at:

www.educationscotland.gov.uk/learningandteaching/thecurriculum/whatiscurriculumforexcellence/ understandingthecurriculumasawhole/index.asp. (accessed 19 February 2015)

Englund, T. (2000) Rethinking democracy and education: towards an education of deliberative citizens, Journal of Curriculum Studies, Vol. 32, No. 2, pp. 305-13.

Faulks, K. (2006) Rethinking citizenship education in England: some lessons from contemporary social and political theory, Education, Citizenship and Social Justice, Vol. 1, No. 2, pp. 123-40.

Frazer, E. (2007) Depoliticising citizenship, British Journal of Educational Studies, Vol. 55, No. 3, pp. 249-63.

Fulkova, M., Straker, A. \& Jaros, M. (2004) The empirical spectator and gallery education, International Journal of Art \& Design Education, Vol. 23, No. 1, pp. 4-15.

Gillborn, D. (2006) Citizenship education as placebo: 'standards', institutional racism and education policy, Education, Citizenship and Social Justice, Vol. 1, No. 1, pp. 83-104.

Hickey-Moody, A. (2013) Youth, Arts and Education: Reassembling Subjectivity through Affect. Abingdon: Routledge.

Houston, S. (2005) Participation in community dance: a road to empowerment and transformation?, New Theatre Quarterly, Vol. 21, No. 2, pp. 166-77.

Illeris, H. (2005) Young people and contemporary art, International Journal of Art \& Design Education, Vol. 24, No. 3, pp. 231-42.

Illeris, H. (2006) Visual events and the friendly eye: modes of educating vision in new educational settings in Danish art galleries, Museum and Society, Vol. 7, No. 1, pp. 16-31.

Karkou, V. \& Glasman, J. (2004) Arts, education and society: the role of the arts in promoting the emotional wellbeing and social inclusion of young people, Support for Learning, Vol. 19, No. 2, pp. 57-65.

Neelands, J. (2009) Acting together: ensemble as a democratic process in art and life, Research in Drama Education, Vol. 14, No. 2, pp. 173-89.

Osler, A. \& Starkey, H. (2003) Learning for cosmopolitan citizenship: theoretical debates and young people's experiences, Educational Review, Vol. 55, No. 3, pp. 243-54.

Pringle, E. (2009) The artist-led pedagogic process in the contemporary art gallery: developing a meaning making framework, International Journal of Art \& Design Education, Vol. 28, No. 2, pp. 17482.

Qualifications and Curriculum Authority (2007) Citizenship Education Key Stage Three Programme of Study (online). Available at: www.standards.dfes.gov.uk/shcemes2/citizenship (accessed 14 June 2007)

Rancière, J. (2004) The Politics of Aesthetics: The Distribution of the Sensible. London: Continuum. 
Rancière, J. (2006) Hatred of Democracy. London: Verso.

Rudduck, J. \& Fielding, M. (2006) Student voice and the perils of popularity, Educational Review, Vol. 58, No. 2, pp. 219-31.

Silverman, D. (2005) Doing Qualitative Research: A Practical Handbook. London: Sage.

Simons, H. \& Hicks, J. (2006) Opening doors: using the creative arts in learning and teaching, Arts and Humanities in Higher Education, Vol. 5, No. 1, pp. 77-90.

Warren, M. (2002) Deliberative democracy, in A. Carter \& G. Stokes [Eds] Democratic Theory Today. Cambridge: Polity Press, pp. 511-30

Young, I. M. (2000) Inclusion and Democracy. Oxford: Oxford University Press. 